\title{
ECONOMIC WAGE AND LEGAL WAGE
}

\author{
George Gorham Groat
}

It is a trite saying that this is an era of discontent. It is equally trite, perhaps, to say that its causes are numerous and complex. Possibly the triteness is the most satisfactory evidence of the truth. Among the causes of restlessness and agitation one of the most important, undoubtedly, is the employer-employee relation. This may conveniently be expressed as the "wage question." It is becoming increasingly clear that upon the way in which the difficulties involved in this issue are met rest not alone the welfare of the people of the United States but as well the permanency of the very foundations of our industrial-politicalsocial institutions.

Unfortunately some groups interested in affecting a remedy are defeating the purpose sought by the method adopted. One of these groups is made up of employers who insist upon a thorough-going individualistic, laissez-faire policy; a policy of personal ownership and management with no assistance or "interference" from outside. Another group is composed of the "agitator" type of worker who would deprive all others of a voice in business control and take over and manage industry unaided; the radical forms of policy represented by the numerous "isms" into which socialism has recently been divided. A third group consists of the well-disposed but troublesome members of society who, without much knowledge and with much less judgment, talk of some plan to be universally adopted as a sure guaranty of the millennium. Thus confusion of method and confusion of understanding inevitably result.

In the presence of such an introduction, it may appear presumptuous to speak of a remedy, and to avoid such an impression it must be said that what follows is not offered as a "solution"; or as in any sense a dogmatic statement of a method or plan of procedure. It does appear clear, however, that there are some issues of economics that must be cleared up and some issues of law to be clarified before definite progress of a permanent character can be made.

The economist has had his opportunity to make a contribution, but whether or not he has succeeded, is an open question. His theoretical offerings have not been impressive to outsiders. Similarly the law has often been called on for assistance and.again it must be said that some of the offerings from this source also lack impressiveness among laymen. Yet from these sources must come, if they come at all, the guiding principles by which a transition may be effected from the troublesome present with its inequalities and its discontent to a better future with greater degree of general welfare and common strivings for mutually satisfactory relations. Thinkers in economics have long sought a 
principle that would at once explain and justify the wages of labor as they develop in the economics of distribution. Likewise jurists and lawyers have sought the legal principles involved in wage bargaining. Success has not yet crowned these efforts.

The history of wage theories is a fascinating study, and while much is learned from its pursuit, it must be said that the conclusions are not convincing either in logical or in scientific method to those who look for a working basis in principle. If the successive economic interpretations of wage principles are reviewed, each interpretation in turn will appear either to one or the other bargainer or to both bargainers as unacceptable. Not to undertake any such full review, reference to three such theories must suffice. Malthus and Ricardo contributed the earliest of these during the first quarter of the nineteenth century. In name it is known as the "iron law" of wages and sought to establish in principle that the wages of labor would tend toward the minimum of subsistence necessary for the laborer's family. A wage below this amount would increase the death rate and decrease the birth rate and consequently give rise to a scarcity of labor. Industry then in order to preserve itself would be obliged to increase wages. When the wages rose above this necessary minimum the birth rate would increase and the death rate would decrease, there would be "an excess of labor," and this excess" would be reduced by the "niggardliness of nature." No comment is necessary to bring out the pessimism and the fatalism of such a view. It soon gave way to a second explanation, somewhat directly related to it; the Wages Fund principle. This theory was generally accepted as orthodox during the middle period of the century. It had a distinguished list of advocates to give it authority and a form of expression such as to make it logically convincing. As James Mill expressed it: ${ }^{1}$ "Universally, then, we may affirm, other things remaining the same, that, if the ratio which capital and population bear to one another remains the same, wages will remain the same; if the ratio which capital bears to population increases, wages will rise; if the ratio which population bears to capital increases, wages will fall." Mill's still more distinguished son, John Stuart Mill, gave to this theory its finished form:" "Wages not only depend upon the relative amount of capital and population, but cannot under the rule of competition be affected by anything else. Wages (meaning, of course, the general rate) cannot rise but by an increase of the aggregate funds employed in hiring laborers, or a diminution of the number of competitors for hire; nor fall, except either by a diminution of the funds devoted to paying labor, or by an increase in the number of laborers to be paid." Even though Mill himself stated later in life that this was. not an adequate or accurate statement, its influence was impaired rather than annulled by the admission. For some time it shared honors with the third principle, to which

${ }^{2}$ Elements of Political Economy (I82I) ch. 2, sec. 2.

'Principles of Political Economy (I848) bk. 2, ch. II, sec. I. 
it has finally yielded almost entirely, the Productivity Theory. This is more broadly a theory of distribution, applicable alike to all four shares; interest, profits and rent as well as wages. For present purposes the statement may be limited to wages. It rests upon the broader principle of diminishing return and marginal or final utility. The name to be most directly associated with the development of this theory is John Bates Clark. It may be variously stated, for it is difficult to formulate it concisely. Clark says:" "The law of wages would stand thus: (I) By a common mercantile rule, all men of a given degree of ability must take what marginal men of that same ability get. This principle fixes the market rate of wages. (2) Marginal men get what they produce. This principle governs wages more remotely, by fixing a natural standard for them." "Each unit of labor, then, is worth to its employer what the last unit produces." And more summarily stated: "As real as gravity is the force that draws the actual pay of men toward a standard that is set by the final productivity law." In another form Seager expresses this law:" "Under conditions of free, all-sided competition the earnings of the marginal, as of other, workmen, tend to correspond to the contributions which they make to production."

Thus one theory has followed another and even now the Productivity Theory is not without rivals. To say that any or all of them are entirely false, would be saying too much. There is no other than an abstract and "long run" application of the best of them to wage controversies. And such applications do not satisfy either the employer -or the employee-side of the controversy. One result is the development of socialist theories and socialist programs directly and obviously based upon them. This gives the one undesirable extreme. Another result is the development of so-called business principles, or theories, and programs resting directly upon them, so generally expressed as Demand and Supply. This opens the door to the opposite and equally undesirable extreme. A third result is the pursuit of Pure Theory from which no immediate program can be directly drawn. The obvious disadvantage of this is that Economic Theory (or the Science of Economics, as a Pure Science) has nothing to offer to the solution of the problem except (and the exception may be regarded as of more or of less importance) a fundamental test of the long run validity of any and every program.

In so far as the employee-interest understands any of these wage theories, no one is satisfactory. The minimum of subsistence theory promises him salvation but no more. The Wages Fund theory gives him all he can get from his employer and promises him that the employer will keep all he does not have to give up. This generates the fighting spirit. The Marginal Productivity Theory tells him that if the group is numerous the marginal product will be less and the wage less. In

${ }^{8}$ The Distribution of Wealth (1899) chs. 7, 8.

- Principles of Economics (3d ed. I923) 26r. 
other words, as laborers come into competition with each other, the wage inevitably falls. There is nothing in any of these when expressed in language intelligible to him that he is willing to accept. The employer-interest does not understand them much more clearly, but is willing to tolerate them, partly because they are "mere theory," and partly because they suggest either a sort of paternal control which he is quite willing to accept, or competition which he quite well understands. On these two bases he has developed his guiding business principle.

A summary of legal or political theories may be made much more briefly. They may all be said to rest upon general principles formulated a century or more ago and still current. They are too familiar to need repetition. All men are created equal; they have, as citizens, certain constitutional or political or civil rights; the rights to life, to liberty, to pursuit of happiness, to property, to equal protection of the laws; and the rights shall not be modified or restricted-citizens shall not be deprived of these rights-except by due process of law. This is all very familiar. While their formulation runs back to much earlier times, and while they are closely related to the "eternal principles" of "justice" and "right," their application has caused increasing difficulties. Both industrial and social conditions have changed within two centuries and have greatly changed in a half century. Interpretation of these political and constitutional principles has been changed also. Extremes appear in these interpretations. Literal interpretation with little if any adaptability gives the one extreme, which appears as an ultra-conservative or reactionary policy and another extreme in the form of ultra-radical or revolutionary programs. Between these extremes, legal or constitutional philosophy is having difficulties. Thus the middle road program of rational progress and sound industrial policy is difficult to find and perhaps even more difficult to keep.

From economic theories, past and present, has come a dangerous admixture of truth and falsehood, of assistance and obstruction, of light and shadow. From legal and constitutional interpretation has likewise come a similar admixture, with one difference of great importance-Economic truth and falsity may be accepted or rejected, and those who differ may defer the application or accept it tentatively for practical working purposes. A legal compound of these ingredients may be made and the conclusion officially or authoritatively declared. When this is done, the conclusion is "so." It is the "law." There is no choice but to act in accordance with it until it is no longer "so"; until it is with equal authority set aside and its place taken with another similarly stated. What then is the purpose of an attempt to bring together a statement of principles of wages on the one hand from economic analysis and on the other from legal analysis? Many excellent purposes may be served by such an effort. The present one is to institute certain comparisons and to point the way to the middle road 
of orderly progress; to make a forward movement possible and to hold its course to a desired end.

Within the limits of a single article, both critical and constructive treatment is not possible. The constructive treatment should wait upon the critical.

The various economic theories above referred to have had just enough of truth in them to be appealing to a practical analyst. Population supplies the labor market. Wage cost is a part of general cost and what is paid for one cost can not be used for another. It is good book keeping. If wage represents what labor produces it must be fair and just. Out of these elements is built up the business principle of demand and supply; the labor market; the wage bargain; the contract agreement; all of which rest upon the virtues of a competitive system. If the employer-interest desires further benefit from the bargaining, this interest seeks to affect the demand side favorably to itself. If the employee-interest is not satisfied, it seeks to control more effectively the supply side of the market. This gives us competition. In a somewhat vague way the community seeks to temper the rigor of the competitive rivalry by public opinion, by consumers' organizations, by law. Of the first two nothing need be said here, but the last one belongs to the discussion.

Competition leads to a wage; but it does not necessarily follow that it leads to an "economic" wage or to a "fair" wage. When an economist assumes that a wage in the competitive market is the expression either of an "iron law," or of a just share of a "fund" of capital, or of the share that labor has "produced," he is more logical than scientific. Before economic theorists can urge their theory (or theories) as a satisfactory guide in wage determination, scientific methods of wage study must be carried farther than they have yet been pushed. The same is true of the legal theories. It cannot be urged as a matter of legal principle that a practical competitive wage is necessarily a "fair" wage. And before lawyers and judges can urge the application of their theories, there must likewise be a departure from deductive logic in the direction of scientific induction. To join these two statements; it must not be assumed either in "argument" or "opinion" that because a conclusion flows with smooth logic from the major premise, that conclusion is necessarily true. The logic of the conclusion is derived from the assumption of the major premise. It is the truth of the major premise that must be tested. "Under conditions of free, all-sided competition," runs the Productivity Theory, "the earnings of marginal, as of other, workmen tend to correspond accurately to the contribution which they make to production." Conditions of free all-sided competition do not exist in modern industrial life. It is doubtful if any approved standard of competition can be found actually existent. But granted that such competition as provided for in this theory does exist, then wages will tend to correspond to the earners' marginal productivity. 
At best it is a tendency. The significance of this term should not be overlooked.

Illustrations from court opinions are too numerous to be exhausted in this connection. The recent District of Columbia Minimum Wage case serves every purpose and its views are fresh in mind. ${ }^{5}$ This is a five to three decision. Assuming that Mr. Justice Brandeis would have voted with the minority as he championed the law as an attorney, it may be called a five to four decision. Another case, very recent, is that of the Kansas Court of Industrial Relations. ${ }^{b}$ This was a unanimous opinion of the United States Supreme Court and reversed a decision of the Kansas State Supreme Court. ${ }^{7}$ The opinion of the Kansas court, though not a unanimous decision, may be taken as a dissenting opinion for present purposes, as the latter was set aside by the former.

Running through the prevailing opinions is the assumption that there are certain general principles which must be applied to all cases, regardless of detailed distinctions between one case and another. It is deductive logic, with very broad generalizations such as have been stated above constituting the major premise and with the preconceptions of the judges, the minor premise leading to the conclusion of unconstitutionality in each case. The minority opinions proceed with about the same assumptions as major premises, but the preconceptions as to minor premises differ and therefore the conclusions differ. It is not easy to arrange the statements in strict syllogistic form because the dissent does not follow the same order as the prevailing opinion and the method of statement in both is more purely literary. In spite of the difficulty, however, the effort is instructive. The fifth amendment guarantees that no citizen shall be deprived of life, liberty or property without due process of law. Liberty to contract is a form of liberty. Therefore no citizen shall be deprived of liberty of contract without due process of law. By this method freedom of contract has been read into the constitution and becomes a constitutional right in itself. It then follows that the act in question restricts freedom of contract. Therefore the act is unconstitutional. But the minority does not think that freedom of contract is a necessary part of the fifth amendment. The "vague contour" of this amendment makes its reference no more specific than "an unpretentious assertion of the liberty to follow the ordinary callings." Later this "innocuous generality was expanded into the dogma, Liberty of Contract. Contract is not specifically mentioned in the text." Therefore freedom of contract is not a specifically implied constitutional right. ${ }^{8}$

${ }^{5}$ Adkins v. Children's Hospital (1923) 26I U. S. 525, 43 Sup. Ct. 394.

-Wolff Packing Co. v. Kansas Court of Industrial Relations (I923) 262 U. S. 522. 43 Sup. Ct. 630. See Comments (1923) 33 Yale Law Journat, ig6.

"Court of Industrial Relations v. Wolff Packing Co. (1921) 109 Kan, 629, 201 Pac. 4I8; (I922) III Kan. 50I, 207 Pac. 806. See (I921) 3I YaLE LAW JourNaL, 206; (Ig22) 3I ibid. 450.

${ }^{8}$ Opinion of Justice Holmes. 
Another view develops as follows-"It is the rule that every possible presumption is in favor of the validity of an act of Congress until overcome by actual doubt." This general rule appears to be nowhere questioned by any authority. And yet the validity of acts of Congress is not only questioned but denied. Of course the test is reasonableness. Justice Sutherland adds to his statement of the rule the following qualification: "But if by clear and indubitable demonstration a statute be opposed to the Constitution, we have no choice but to say so." This creates a distinction between what appears to be and what is. To the majority the statute by "clear and indubitable demonstration" is opposed to the Constitution and the court has "no choice but to say so." In the dissent the matter is handled in a different manner. From this point of view it appears that public welfare is distinctly related to this legislation. The means of securing this welfare have the approval of Congress, of many states and of foreign governments. "When so many intelligent persons, who have studied the matter more than any of us can, have thought that the means are effective and are worth the price it seems to me impossible to deny that the belief reasonably may be held by reasonable men." To this statement Justice Holmes adds: "To me-the power of Congress seems absolutely free from doubt." Chief Justice Taft says: "Congress took this view-and we cannot say it was not warranted in so doing." In connection with this same issue of reasonableness both dissenting opinions lay emphasis upon the view that experience provides support for the belief that a "sweating wage" has a great and direct tendency "to bring about an injury to the health and morals of workers," and that much expert testimony supports such a conclusion. The minority finds this evidence to bear witness of reasonable doubt; the majority finds it "inferesting but only mildly persuasive."

This may be recast into a form about as follows: If the legislature passed the statute, they did not act reasonably. It was only alleged reasonableness. Even though some members of the court vote to sustain the statute, they act only on alleged reason. It is not sufficient that the act appear reasonable to anybody or to everybody. It must $b e$-clearly and indubitably $b e$-reasonable. Inevitably follows the question; how is the distinction to be made clear between what appears and what is. The working adjustment of the difficulty is that a majority vote determines what is-that is to say, if the reasonableness appears to the majority to $b e$, then it is, and the minority are deceived by appearances. But Justice Sutherland would not consent to this method generally, since he says that the evidence which leads the act to appear reasonable to three of the members of the court tends to "establish the desirability or undesirability of the legislation; but they reflect no legitimate light upon the question of its validity, and that is what we are called upon to decide. The elucidation of that question can not be aided by counting heads." Numbers do not make reasonableness. 
This confusion may be dissolved without great difficulty. On the one hand it may be said that the police power is not to be extended to further encroachment upon the freedom of action of citizens unless the result of this loss be offset by a greater gain. Whether or not the result is the greater gain is to be determined by scientific inquiry through expert investigation and conclusion in accordance with correct scientific method. It is true that numbers do not necessarily count. It is scientific method that counts in validating the conclusion. The conclusion reached will be reasonable-that is to say, it will stand the test of science. On the other hand it may be declared that the use of police power depends upon precedent. If no precedent is found, the new venture is not valid. Every new venture creates "reasonable presumption" against it. The burden of proof lies with the advocates of the new departure. This may be cast into form:-A new departure from precedent uses of police power is of doubtful validity. It may not appear so to some, but it is so nevertheless. This is logic. The conclusion is logical. Now, if these two explanations be placed so as to run parallel, it appears that the difference of opinion as to reasonableness may rest upon two different conceptions of what is reasonable; (I) what is scientific, and (2) what is logical. The prevailing opinion adopts logical method. The dissenting opinion follows scientific method. The conclusions are divergent. It may be worth while to note this more especially in the opinions. The prevailing opinion finds a difference in kind between police power to determine, on the one hand, the maximum number of hours in the work day for women (Muller $v$. Oregon $^{9}$ ) and, on the other hand, the minimum wages to be paid. In the view of the prevailing opinion "the essential characteristic of the statute now under consideration differentiates it from the laws fixing hours of labor." Fixing hours of labor is a matter dealing with "the incidents of the employment" and has no necessary effect upon "the heart of the contract." "The statute in question ... . . differs from (legislation fixing hours) in every material respect. ... It is simply and exclusively a price-fixing law, confined to adult women .... who are legally as capable of contracting for themselves as men." Chief Justice Taft (dissenting opinion) asserts that the difference, in so far as any real difference exists, is not a substantive difference-" "a restriction as to one (wages) is not any greater in essence than the other (hours) and is of the same kind." The conclusion of the majority "appears to me to exaggerate the importance of the wage term of the contract of employment as more inviolate than its other terms."

Another difference of interpretation grows out of the significance attached to former cases. The prevailing opinion refers to the New York Bake Shop case ${ }^{10}$ which refused to sustain a statute in that state limiting the hours of adult males in bakeries. Justice Sutherland says

' (Ig08) 208 U. S. 412, 28 Sup. Ct. 324.

${ }^{10}$ Lochner v. New York (Ig05) I98 U. S. 45, 25 Sup. Ct. 539. 
that "subsequent cases in this court have been distinguished from that decision, but the principles therein stated have never been disapproved." The logic follows-Legislators cannot limit the hours of labor of adult male citizens in bakeries. Women now have equal political rights with men (nineteenth amendment). The sex distinction therefore disappears, civil differences between the sexes "have now come almost, if not quite, to the vanishing point." And since the wage is a price-fixing element, the most important element in the contract, the Lochner principle, is of even greater significance. Differing with this, the Chief Justice cites the more recent case, Bunting $v$. Oregon, ${ }^{11}$ in which this court sustained an Oregon statute establishing a legal ten-hour day for all male employees in occupations generally. This was certainly a recognition of the broader legislative discretion. Justice Sutherland says that the Lochner case has been distinguished from all later cases and so its principles still hold. Chief Justice Taft says that there is no reference in the Bunting case to the Lochner case and since "the opinion in the Bunting case does not mention the Lochner case, . . . . certainly there was no attempt to distinguish it in the Bunting case.... . It is impossible for me to reconcile the Bunting case and the Lochner case, and I have always supposed that the Lochner case was thus overruled sub silentio." Justice Holmes adds: "After Bunting v. Oregon I had supposed that . . . Lochner $v$. New York would be allowed a deserved repose."

Not to continue the contrasts to the point of exhaustion, others may be briefly noted, with omission of citations from the opinions. Civil rights exist regardless of sex, declares the prevailing opinion. Especially emphasis is laid on the nineteenth amendment. This covers as a general proposition the freedom of contract. The dissenting opinion stresses the physiological distinction and does not yield so fully to the effect of the amendment. The Chief Justice, in dissent, does not think that the amendment makes necessary a modification of former constitutional construction where that construction is based on physical differences between men and.women. Justice Holmes declares; "it will need more than the nineteenth amendment to convince me that there are no differences between men and women, or that legislation cannot take those differences into account." The purpose of this discussion will be served by the citation of one extract somewhat at length. It illustrates a rather prevalent mode of reasoning.

"If in the interest of the public welfare the police power may be invoked to justify the fixing of a minimum wage, it may, when the public welfare is thought to require it, be invoked to justify a maximum wage. The power to fix high wages connotes, by like course of reasoning, the power to fix low wages. If, in the face of the guaranties of the Fifth Amendment, this form of legislation shall be legally justified, the field for the operation of the police power will have been widened to a

${ }^{11}$ (I917) 243 U. S. 426,37 Sup. Ct. 435. 
great and dangerous degree. If, for example, in the opinion of the future law makers, wages in the building trades shall become so high as to preclude people of ordinary means from building and owning homes, an authority which sustains the minimum wage will be invoked to support a maximum wage for building laborers and artisans, and the same argument which has been here urged to strip the employer of his constitutional liberty to contract in one direction will be utilized to strip the employee of his constitutional liberty of contract in the opposite direction."

The reply of the Chief Justice to this statement is brief. "This, I submit, is a non sequitur." The distinction is "a matter of degree and practical experience and not of pure logic."

The summary of the two opinions may be found in the following expressions. The prevailing opinion concludes that the act is "so clearly the product of a naked, arbitrary exercise of power that it clearly cannot be allowed to stand under the Constitution of the United States." Chief Justice Taft, in his dissent, says that since Congress took the view that there was definite and clearly recognized need for the statute in the interest of public health and welfare, "we cannot say that it was not warranted" in passing the law. Justice Holmes concludes: that since Congress held the legislation to be reasonable, its constitutionality seems "absolutely free from doubt." Each side is absolutely certain of the reasonableness of its position and yet they do not agree.

To return to the earlier portion of this article; it is asserted that an acute industrial situation is developing and the storm-center is forming around the contention of wages. Clearly the two agencies that should contribute most to the favorable solution of the difficulties are the industrial principles worked out through the scientific agencies of economics and the legal principles scientifically applied by legislatures and squared with our fundamental principles of constitutional government by the courts by methods equally scientific. It is doubtful if either agency is meeting its full responsibility in this obligation. Economists adopt involved statements of tendencies which, other things being equal, will express themselves in the long run. This is good as pure theory. Applied, it develops real differences in the shape of varying programs. Practice must make tests of these programs, and the greatest practical service of economists will be to safeguard the programs against extremes in either direction. Within the limits of the extremes, they may divide in advocacy of one or another experiment. So long as the need for an experiment-is established with scientific (reasonable) clearness, it is not sufficient to say simply that there can be no harm in making it. More must be said. It must be declared that the experiment is positively a contribution to the solution of the problem. If the experiment fail, either in whole or in part, a further scientific study will reveal the causes of failure.

Quite similarly it may be said that legal principles are formulated in 
terms of generality which express a truth-a fundamental truth-but express it in abstract terms, or in terms of pure legal theory. These are good as legal theory. Applied, they develop real differences in judgment on various proposed programs. It is equally true that practice must take tests of these programs, and the greatest service of legislators will be to examine scientifically the need for these experiments (pass upon their reasonableness) and the greatest practical service of the courts will be to make possible these reasonably necessary experiments within the limits of constitutional (reasonable or scientific) procedure. The limitations will prevent extremes in either direction and the boundaries will at best be difficult to determine. Within the extremes, it may be declared, it is not the function of the court to decide whether or not the experiment shall be made. To the legislators is assigned that task. Equally, also, it may be said that it is not sufficient for the court to say that it is not unreasonable to interpret a general principle of the constitution so that the proposed experiment may be tried. To be of the greatest positive service in constructive progress the court must conclude that such experiments are positively reasonable (scientific) when Congress has determined that they are reasonable (scientific). In many cases the prevailing opinion, or even the unanimous opinion, has been to the effect that Congress deemed the policy expressed in the act desirable; and therefore valid. Further it has been pointed out that if the policy proves undesirable as shown by results, it lies with Congress to repeal it. If further developed, this attitude of the courts holds promise of making a definitely valuable contribution to our Constitutional law. It is also frequently pointed out that the choice of industrial policy lies with public opinion reflected in legislation. It is not for the courts to pass upon such policy in accordance with their own industrial or economic views. This may with great profit become the generally accepted attitude of the courts.

If both economics and Law join hands in departing from pure logic, in refraining from shaping their conclusions in accordance with logical reductio ad absurdum, in declining, with Mr. Justice Holmes, to act upon the belief that general propositions decide concrete cases, there is the hope that Economic theory of wages and legal theory of wages may be fused into a practicable, workable, scientific, reasonable, constitutional, and possibly logical basis upon which to work out the difficulties of the times.

There are evidences that this is being slowly accomplished. There are also evidences that the progress is dangerously slow. The courts, entitled to the greatest respect, and justly so entitled, have in their records the New York Tenement House case, ${ }^{12}$ the Bake Shop case, ${ }^{13}$ the New York State Workmen's Compensation case, ${ }^{14}$ the Child Labor

1 Matter of Jacobs (I885) 98 N. Y. 98.

${ }^{13}$ Lochner v. New York, supra note 10.

"Ives v. South Buffalo R. R. (19II) 20I N. Y. 27I, 94 N. E. 43r. 
cases, ${ }^{15}$ as well as the Minimum Wage case. These and other cases have occasioned criticism from high and conservative sources. This list should not be extended if the courts are to retain the exalted position in our government that has almost universally been accorded them.

Critical in a different way, it is here suggested that many changes have come about in industry since 1787 , and that the Amendments to our Constitution have not grown directly out of any of them. These changes are especially evident in that successor to the master and servant relation the employer and employee relation-which expresses. a new industrial era quite revolutionary in the extent of the changes. An eighteenth century constitution cannot, without change, be fitted to these twentieth century conditions. The new wage relations must be given scope to adjust themselves. Quite necessarily there must be experimentation. Minimum wage, minimum hours, standard of living, collective bargaining, welfare work, arbitration, both compulsory and voluntary; these are only a few of the list of proposed measures none of which can be scientifically shown to be either good or bad as concrete policies by method of logic. The Supreme Court has declared the wage fixing function of the Kansas Industrial Court to be an activity in violation of the Constitution of the United States. Possibly they were right. Granting that the people of Kansas have a republican form of government, it must be admitted that those people desired to try this method of handling a phase of the wage question. There was an opportunity to try a plan and get some experience based on its operation. If the federal Supreme Court had appreciated this, it would seem that the law might have appeared reasonable. The court has shut the door to that effort. It has done so on the basis of logic, not on the basis of either science or the scientific spirit.

There are many experiments to be made. Many of them should be made. If it is made possible to experiment, the contending interests will have ground on which to settle their differences by constitutional rivalry. If this opportunity is not afforded by the courts through the agency of constitutional interpretation, it must come about through the less desirable method of constitutional amendment, a method less desirable for more reasons than one. Should this latter not be accomplished, there may appear a reshaping of the conflicting forces with results that there is no occasion here for naming. Extremes gather force only against continued resistance.

A further discussion of the programs for wage adjustment would lead to the constructive consideration of this theme and that must be undertaken at another time.

${ }^{15}$ Hammer v. Dagenhart (1918) 247 U. S. 25I, 38 Sup. Ct. 529; Bailey v. Drexel Furniture Co. (1922) 259 U. S. 20, 42 Sup. Ct. 449. 